\title{
Isolation, Identification and Characterization of Trichoderma Species as a Potential Biocontrol Agent against Ceratocystis paradoxa
}

\author{
Sagarika Kannangara ${ }^{1}$, R. M. G. C. S. Dharmarathna ${ }^{1}$ and D. L. Jayarathna ${ }^{2}$ \\ Received: 03 ${ }^{\text {rd }}$ September 2016 / Accepted: 06 ${ }^{\text {th }}$ June 2016
}

\begin{abstract}
Ceratocystis paradoxa is a plant pathogen causing diseases in several plants including coconut (Cocos nusifera). Infected coconut plants manifest "Stem bleeding" which is very common in Hambantota district in Sri Lanka. Coir and coir pith obtained from coconut husk provide substrates for the growth of the pathogen. The use of biological control agents (BCAs) has gained more attention in controlling plant pathogens because it minimizes the application of synthetic pesticides. In many researches, various strains of Trichoderma species have been studied to be used as BCAs against many plant pathogens. The present investigation was carried out in an attempt to isolate various strains of Trichoderma spp. from soil, litter and coir samples collected from different locations in Lunuwila area in the North Western Province of Sri Lanka, and to evaluate their potential as BCAs in controlling C. paradoxa. Several Trichoderma spp. were isolated into PDA plates. Colony morphology and morphological features of sporulating structures and spores were compared among the Trichoderma isolates. Genomic variability of isolates was determined by RFLP analysis of the PCR amplified DNA for the ITS region of the isolates using AluI enzyme. Potential ability of Trichoderma isolates in controlling the pathogen was observed using dual culture technique. Accordingly, ten different Trichoderma isolates were identified from soil but none from coir. The isolates were identified as T. viridae, T. polysporum, and T. harzianum. As $B C A s$, almost all Trichoderma isolates exhibited more than $60 \%$ growth inhibition of C. paradoxa on the seventh day of incubation in a dual culture.
\end{abstract}

Keywords: Trichoderma, Ceratocystis paradoxa, Biological control, Growth inhibition, DNA

\section{INTRODUCTION}

Ceratocystis paradoxa is a soil borne pathogen which causes diseases in several economically important plants such as sugarcane, pineapple, banana, cocoa, coconut and oil palm. Due to its infection, plant trunk either collapses on itself or the canopy suddenly falls off, both without warning. 'Stem bleeding' is a common symptom observed on Cococs nucifera (coconut) (PaulinMahady et al., 2002). It was reported by Petch for the first time in Sri Lanka during 1906 (Warwick and Passos, 2009). In 1995 this disease has been discovered in Hambantota district including areas such as Ambalantota, Beliatta, Netolpitiya, Tissamaharamaya and Weeraketiya. Two adjoining districts of Matara and Rathnapura have been reported to have affected palms especially in Dickwella and in Embilipitiya areas where coconut trees are grown in home lands. Although, the area was free from serious disease epidemics in the past, an epidemic of stem bleeding was reported to be spreading during 1995 (Wijesekara et al., 1998).

Chemicals such as methyl bromide and a fungicide named Bavistin are being frequently used to control the pathogen and to protect fields from the pathogen attack. However, use of chemicals is expensive and the heavy usage of chemicals is hazardous to the environment

\footnotetext{
1 Department of Botany, Faculty of Science, University of Kelaniya, Sri Lanka.

2 Department of Microbiology, Faculty of Science, University of Kelaniya, Sri Lanka.
} 
(Talukder et al., 2007). Biological control of plant pathogens using microorganisms has been considered as more natural and an environmentally acceptable alternative to the chemical controlling methods.

Trichoderma spp. have been found as an effective BCAagainst many soil borne pathogens (Eziashi et al., 2006). Trichoderma controls pathogens in an indirect way by producing several groups of antibiotics that inhibit the growth of the pathogen. Apart from that, there are direct methods showing antagonism against the pathogen which is called mycoparasitism. Trichoderma species can also inhibit or reduce the growth of plant pathogens especially fungi, through competition for space, enzyme substrates, nutrients, and or oxygen (Sanchez et al., 2006).

Therefore, Trichoderma species have been used as BCAs for phytopathogenic fungi to control plant diseases. The strains like $T$. viridae, $T$. polysporum, T. hamatum, T. aureoviridae, $T$. harzianum have the ability to kill plant pathogens. Remarkable results of control have been observed with strains of $T$. virens against Pythium ultimum infecting cotton and Rhizoctonia solani infecting tobacco and $T$. harzianum against Verticillium dahliae infecting potato (Benitez et al., 2004). It has been reported of the effective use of T. hamatum for the control of Pythium seed rot and Rhizoctonia root rot in pea (Eziashi et al., 2006).

Moreover, T. viride has a very good potential in controlling $C$. paradoxa successfully. It was also reported that $T$. polysporum, T. hamatum, and $T$. aureoviride have the ability of controlling C. paradoxa successfully (Eziashi et al., 2010).

The present study was undertaken in an attempt to isolate Trichoderma spp. from the sites near Lunuwila area in the North Western Province of Sri Lanka, where coir processing is being done and also to identify Trichoderma spp. using morphological and molecular techniques, and to investigate the potential in different
Trichoderma isolates to control $C$. paradoxa that has been isolated from the same sites. Apart from that it was hypothesized that most of Trichoderma isolates can inhibit the growth of $C$. paradoxa according to their parallel evolution in the same location.

Random amplified polymorphic DNA (RAPD) which includes amplified essentially unknown segments of DNA and internal transcribe spacer-polymerase chain reaction (ITS-PCR) are used to carryout molecular characterization of BCAs (Chakraborty et al., 2010, Mbwana et al., 2006). In this study, amplification of $5.8 \mathrm{~S}$ rRNA gene using primer pair ITS1 and ITS4 has been done. The two spacers, together with the $5.8 \mathrm{~S}$ gene, are normally referred to as the ITS region (Schoh et al., 2012). This is a very good tool of species identification because rRNA genes are universally conserved, while the ITS region is highly variable. The ITS region evolves very fast and even within a genus it may vary among species. Therefore, the sequences of these regions can be used for identification of closely related species (White et al., 1990). Restriction digestion of the amplified DNA using AluI enzyme was performed to differentiate the Trichoderma isolates depending on their genomic variability. At present, RFLP is recognized as a very good technique to differentiate species, because cleavage of DNA molecules at specific sites (Beckmann and Soller, 1983). So that, the molecular characterization was also applied during the present study in order to differentiate the isolated Trichoderma species.

\section{MATERIALS AND METHODS}

\section{Sample Collection}

Both fresh and decaying coir samples from old and new heaps were collected into clean polythene bags from Coir Research and Development Institute, St. Antony's Mill and Keerti Mill in Lunuwila area in the North 
Western Province of Sri Lanka. The soil samples along with the litter materials were randomly collected from the same locations and stored at $4{ }^{\circ} \mathrm{C}$ until used.

\section{Isolation of Trichoderma}

Trichoderma spp. were isolated from coir and soil into PDA plates using spread plate technique. Litter materials were cultured in PDA plates for the isolation of the fungi. All of the Trichoderma spp. growing on PDA were then isolated into pure cultures.

\section{Identification of Trichoderma Isolates}

Colony morphology of the each Trichoderma isolate was recorded. For microscopic observations specimens were prepared according to the sticky tape method (Flegel, 1980). Using graticular calibrated phase contrast microscope, spore shape, size and mycelial width of each isolate were measured.

\section{Testing the Biological Control Ability of Trichoderma Isolates}

Potential ability of each Trichoderma isolate in controlling $C$. paradoxa was studied using dual culture technique (Imtiaj and Lee, 2008).

The percentage of inhibition (I\%) on the mycelial growth of $C$. paradoxa was calculated using the following formula (Imtiaj and Lee, 2008).

$\mathrm{I} \%=(\mathrm{r} 1-\mathrm{r} 2) / \mathrm{r} 1 \times 100$

(r1 is the radial growth of C.paradoxa in control, while $\mathrm{r} 2$ is the radial growth of $C$. paradoxa in dual culture plate)

Hyphal interactions between Trichoderma and C. paradoxa were observed using slide culture technique.

Molecular Characterization of Trichoderma Isolates

For DNA extraction hyphal tips of Trichoderma isolates were inoculated to $1.5 \mathrm{ml}$ of eppendorf tube filled with $1 \mathrm{ml}$ of Potato dextrose broth and allowed to grow for 72 hours at $28 \pm 2{ }^{\circ} \mathrm{C}$ incubation. The mycelial mat produced after the inoculation, was pelleted by centrifugation for 5 minutes at $13000 \mathrm{rpm}$ in a microcentrifuge. The pellet was washed with $500 \mu \mathrm{l}$ of TE (TrisCl, EDTA) buffer for pelleting again. The TE buffer was decanted and $300 \mu \mathrm{l}$ of extraction buffer $(200 \mathrm{mM}$ Tris $\mathrm{HCl} \mathrm{pH} 8.5,250 \mathrm{mM}$ $\mathrm{NaCl}$, and $25 \mathrm{mM}$ EDTA, 0.5\% SDS) was added to the pellet. The mycelium was crushed with a sterile toothpick. Subsequently, $150 \mu 1$ of $3 \mathrm{M}$ Sodium acetate, $\mathrm{pH} 5.2$ was added and tubes were placed at $-20{ }^{\circ} \mathrm{C}$ for 30 minutes. Tubes were centrifuged $10000 \mathrm{rpm}$ for 10 minutes. The supernatant was transferred to another sterile eppendorf tube. Equal volume of isopropanol was added and kept for 10 minutes at room temperature. DNA was precipitated by centrifugation at $12000 \mathrm{rpm}$ for 10 minutes. After a wash with $70 \%$ ethanol, the pellet was dried for 5 minutes and re-suspended in $50 \mu 1$ of TE to make DNA suspension.

ITS-PCR was done for each sample in a $25 \mu 1$ reaction mixture. Each reaction mixture was contained with $0.2 \mathrm{X}$ PCR buffer, $0.16 \mathrm{mM}$ $\mathrm{MgCl}_{2}, 0.01 \mu \mathrm{M}$ ITS1 (forward primer), 0.01 $\mu \mathrm{M}$ ITS4 (reverse primer), $0.144 \mathrm{mM} \mathrm{dNTP}$, $0.5 \mathrm{mU} / \mu 1 \mathrm{Taq}$ polymerase, $2.00 \mu 1$ of template DNA and $14.95 \mu$ of PCR water. The Thermal cycler was programmed for 30 cycles of initial denaturation at $95^{\circ} \mathrm{C}$ for 5 minutes followed by denaturation at $95{ }^{\circ} \mathrm{C}$ for one minute. Primer annealing at $55{ }^{\circ} \mathrm{C}$ for 1 minute, elongation at $72{ }^{\circ} \mathrm{C}$ for 2 minutes, final extension at $72{ }^{\circ} \mathrm{C}$ for 10 minutes and final hold $4{ }^{\circ} \mathrm{C}$.

RFLP for each PCR product was studied with AluI enzyme. Restriction digestion mixture was prepared in $30 \mu \mathrm{l}$ volume containing $0.66 \mathrm{X}$ Buffer for restriction enzyme, $1 \mathrm{U} / \mu \mathrm{l}$ AluI restriction enzyme, $15 \mu 1$ of PCR product and $11.5 \mu$ l of water with 1 -hour incubation at $37^{\circ} \mathrm{C}$ and enzyme inactivation at $70^{\circ} \mathrm{C}$ for 5 minutes. 
DNA was visualized by agarose gel electrophoresis. The gel was allowed to run at $75 \mathrm{~V}$ for 120 minutes and observed under UV trans-illuminator at $254 \mathrm{~nm}$ wave length.

\section{RESULTS AND DISCUSSION}

\section{Isolation and Identification of Trichoderma}

Ten different Trichoderma isolates have been identified from the collected samples. The identification was carried out according to the morphological and microscopic characteristics followed by the online identification key provided by Samuels and his coworkers (http://nt.arsgrin.gov/taxadescriptions/keys/ FrameKey.cfm? gen=Trichoderma) and the Compendium of soil fungi (Domsch et al., 1980).

Use of morphological characteristics is one of the conventional methods to identify Trichoderma species and it remains as a potential method to identify Trichoderma up to genus level (Samuels et al., 2002).

Table 01 indicates the colony morphology and microscopic characteristics such as length and width $(\mu \mathrm{m})$ of spore, phialides and mycelia of 10 Trichoderma isolates. Pure Trichoderma colonies grown in the PDA plates at room temperature showed five different growth patterns with different colony characteristics. The color of the colonies varied from light green to dark green. Each Trichoderma isolate having similar colony morphology, may be, most probably, belong to the same species. But colony characteristics are not sufficient to identify them into species level. Therefore, the characteristics of sporulating structures and spores were used. Morphology of the spores and sporulating structures of the isolates were more or less similar, but significantly different in length and width.

Different terms have been used in describing the shapes of the conidia because no systematic rule was established in defining the shapes of the conidia. Also the description of the shapes of conidia may be subjective. Therefore, the descriptions of the shapes of conidia were not good criteria in identifying most of the isolates. The size of spore and phialide sizes were really useful in the identification of possible Trichoderma species.

Identified Trichoderma species are indicated in Table 02 and most of the isolated species from different sites were more or less similar. Isolate 5 was easily identified as $T$. polysporum. The ellipsoidal conidia, phialides of $7.167 \mu \mathrm{m}$ length and yellow pustules were the key to distinguish those isolates as T. polysporum. With the spore and phialide sizes, and other microscopic and macroscopic characters such as presence of sterile hyphal elongations, absence of pustules, isolates 2 and 9 were able to be identified as T. viridae. Similarly isolates 4 and 7 were proposed as $T$. viridae especially using spore and phialide sizes as key characteristics. The reason for having different colony morphology may be due to different strains of $T$. viridae. Small spore size $(2.6 \mu \mathrm{m})$ was the key character of isolates 1 and 8 , which were used to predict them as T. harzianum. Similarly isolates 3, 6 and 10 contained small spore size $(3.3 \mu \mathrm{m})$ which was the key feature to identify them also as $T$. harzianum. The difference that was detected in isolates 3, 6 and 10, was the presence of pustules in the culture media whereas isolates 1 and 8 have no pustules. Pustules were not a key character to differentiate them, because $T$. harzianum may or may not contain pustules in the culture. Therefore, those isolates may be different strains of the same species identified as T. harzianum. T. harzianum can be divided in to three, four, or five sub specific groups, depending on the strains (Grondona et al., 1997). Isolate 3,6 and 10 produced yellow coloured water soluble pigments in PDA plates. The production of a diffusible orange pigment in the medium with gelatin by $T$. harzianum was reported by Rifai (1969) (Grondona et al., 1997). 
Table 01: Morphological and microscopic characteristics of Trichoderma isolates.

\begin{tabular}{|c|c|c|c|c|c|}
\hline Isolate & Colony on PDA & & Spores & Phialides & Mycelia \\
\hline \multirow{2}{*}{1} & \multirow{2}{*}{$\begin{array}{l}\text { Dark green } \\
2 \text { rings per plate }\end{array}$} & Width $(\mu \mathrm{m})$ & $2.60 \pm 0.22$ & $2.083 \pm 0.25$ & $5.20 \pm 0.10$ \\
\hline & & Length $(\mu \mathrm{m})$ & $2.60 \pm 0.19$ & $8.167 \pm 0.34$ & \\
\hline \multirow{2}{*}{2} & \multirow{2}{*}{$\begin{array}{l}\text { Dark green } \\
\text { 3-4 rings per plate }\end{array}$} & Width $(\mu \mathrm{m})$ & $4.60 \pm 0.15$ & $3.416 \pm 0.28$ & $5.20 \pm 0.08$ \\
\hline & & Length $(\mu \mathrm{m})$ & $4.60 \pm 18$ & $7.916 \pm 0.47$ & \\
\hline \multirow[b]{2}{*}{3} & $\begin{array}{l}\text { Dark green } \\
\text { Rings absent }\end{array}$ & Width $(\mu \mathrm{m})$ & $3.30 \pm 0.11$ & $3.667 \pm 0.33$ & $3.70 \pm 0.27$ \\
\hline & $\begin{array}{l}\text { Irregular margin } \\
\text { Yellow coloured } \\
\text { pigment }\end{array}$ & Length $(\mu \mathrm{m})$ & $3.30 \pm 0.09$ & $5.916 \pm 0.51$ & \\
\hline \multirow[b]{2}{*}{4} & Bright green & Width $(\mu \mathrm{m})$ & $5.10 \pm 0.12$ & $3.500 \pm 0.45$ & $5.20 \pm 0.11$ \\
\hline & $\begin{array}{l}\text { Rings at early stage, } \\
\text { over the plate later }\end{array}$ & Length $(\mu \mathrm{m})$ & $5.10 \pm 0.15$ & $9.667 \pm 0.65$ & \\
\hline \multirow{2}{*}{5} & $\begin{array}{l}\text { Yellow green } \\
\text { Rings absent }\end{array}$ & Width $(\mu \mathrm{m})$ & $2.87 \pm 0.40$ & $3.750 \pm 0.44$ & $4.90 \pm 0.23$ \\
\hline & $\begin{array}{l}\text { Yellow pustules over } \\
\text { the plate }\end{array}$ & Length $(\mu \mathrm{m})$ & $3.50 \pm 0.27$ & $7.167 \pm 0.58$ & \\
\hline \multirow[b]{2}{*}{6} & Dark green & Width $(\mu \mathrm{m})$ & $3.30 \pm 0.16$ & $3.583 \pm 0.35$ & $3.80 \pm 0.30$ \\
\hline & $\begin{array}{l}\text { Rings absent } \\
\text { Irregular margin }\end{array}$ & Length $(\mu \mathrm{m})$ & $3.30 \pm 0.18$ & $6.083 \pm 0.50$ & \\
\hline \multirow{2}{*}{7} & $\begin{array}{l}\text { Bright green } \\
\text { Rings at early days }\end{array}$ & Width $(\mu \mathrm{m})$ & $5.10 \pm 0.16$ & $3.500 \pm 0.36$ & $5.20 \pm 0.24$ \\
\hline & $\begin{array}{l}\text { Colony over the plate } \\
\text { later }\end{array}$ & Length $(\mu \mathrm{m})$ & $5.10 \pm 0.14$ & $9.416 \pm 0.73$ & \\
\hline \multirow{2}{*}{8} & \multirow{2}{*}{$\begin{array}{l}\text { Dark green } \\
2 \text { rings per plate }\end{array}$} & Width $(\mu \mathrm{m})$ & $2.50 \pm 0.23$ & $2.083 \pm 0.29$ & $5.20 \pm 0.21$ \\
\hline & & Length $(\mu \mathrm{m})$ & $2.50 \pm 0.20$ & $8.250 \pm 0.54$ & \\
\hline \multirow{2}{*}{9} & \multirow{2}{*}{$\begin{array}{l}\text { Dark green } \\
\text { 3-4 rings per plate }\end{array}$} & Width $(\mu \mathrm{m})$ & $3.40 \pm 0.17$ & $3.333 \pm 0.28$ & $5.20 \pm 0.19$ \\
\hline & & Length $(\mu \mathrm{m})$ & $3.40 \pm 0.18$ & $8.000 \pm 0.50$ & \\
\hline \multirow{2}{*}{10} & \multirow{2}{*}{$\begin{array}{l}\text { Dark green } \\
\text { Rings absent } \\
\text { Irregular margin }\end{array}$} & Width $(\mu \mathrm{m})$ & $3.30 \pm 0.15$ & $3.583 \pm 0.44$ & $3.70 \pm 0.26$ \\
\hline & & Length $(\mu \mathrm{m})$ & $3.30 \pm 0.13$ & $6.000 \pm 0.65$ & \\
\hline
\end{tabular}

Almost all Trichoderma isolates grown in the PDA plates showed confluent growth within 4 days because of their higher growth rates (Table 03). But there were slight variations among some of the isolates. Among them, isolates 1, 8 (T. harzianum) and 7, 8 (T. viridae) significantly expressed the highest growth. However, the growth rate of isolate 5 (T. polysporum) was comparatively higher than that of isolates 2 and 9 (T. viridae). Meanwhile, the slowest growth rates were expressed by isolates 3,6 and 10 ( $T$. harzianum).

\section{Restriction Digestion of ITS Region with AluI Enzyme}

However, information from morphological study is not really specific to identify precisely a Trichoderma species because Trichoderma species have relatively few morphological characters and limited variations (Shahid et al., 2013) that may cause overlapping and misidentification of the isolates. Therefore, there is a necessity to use molecular techniques to compensate for the limitations of morphological characterization. 
Table 02: Trichoderma spp. isolated from different sites

\begin{tabular}{cll}
\hline Isolate number & \multicolumn{1}{c}{ Site of collection } & \multicolumn{1}{c}{ Trichoderma spp. } \\
\hline 1 & Coir Research and Development Institute & T. harzianum \\
2 & Coir Research and Development Institute & T. viridae \\
3 & Coir Research and Development Institute & T. harzianum \\
4 & Coir Research and Development Institute & T. viridae \\
5 & St. Antony's Mill & T. polysporum \\
6 & St. Antony's Mill & T. harzianum \\
7 & St. Antony's Mill & T. viridae \\
8 & Keerthi Mill & T. harzianum \\
9 & Keerthi Mill & T. viridae \\
10 & Keerthi Mill & T. harzianum \\
\hline
\end{tabular}

Table 03: The average colony diameters of each Trichoderma isolates grown in PDA plates

\begin{tabular}{|c|c|c|c|c|c|}
\hline \multirow{2}{*}{ Isolate } & \multirow{2}{*}{ Species } & \multicolumn{4}{|c|}{ Average colony diameter $(\mathrm{cm})$} \\
\hline & & Day 1 & Day 2 & Day 3 & Day 4 \\
\hline 1 & T. harzianum & $2.90 \pm 0.15$ & $7.40 \pm 0.07$ & 9.00 & 9.00 \\
\hline 2 & T. viridae & $2.50 \pm 0.03$ & $5.60 \pm 0.08$ & $6.90 \pm 0.08$ & 9.00 \\
\hline 3 & T. harzianum & $3.30 \pm 0.03$ & $4.10 \pm 0.27$ & $6.40 \pm 0.15$ & 9.00 \\
\hline 4 & T. viridae & $4.10 \pm 0.07$ & $8.00 \pm 0.22$ & 9.00 & 9.00 \\
\hline 5 & T. polysporum & $2.00 \pm 0.10$ & $6.10 \pm 0.10$ & $7.50 \pm 0.08$ & 9.00 \\
\hline 6 & T. harzianum & $3.30 \pm 0.10$ & $3.90 \pm 0.2$ & $6.30 \pm 0.12$ & 9.00 \\
\hline 7 & T. viridae & $3.90 \pm 0.26$ & $8.30 \pm 0.12$ & 9.00 & 9.00 \\
\hline 8 & T. harzianum & $3.00 \pm 0.13$ & $7.40 \pm 0.08$ & 9.00 & 9.00 \\
\hline 9 & T. viridae & $2.60 \pm 0.05$ & $4.90 \pm 0.1$ & $6.70 \pm 0.20$ & 9.00 \\
\hline 10 & T. harzianum & $3.20 \pm 0.05$ & $3.90 \pm 0.12$ & $6.40 \pm 0.07$ & 9.00 \\
\hline
\end{tabular}

According to the gel picture (Figure 01), the PCR fragments in lane 13 and 16 of the isolates 4 amplified 5.8S rDNA flanking ITS1 and ITS4, and 7 which were identified as T. viridae and was around 500bp length. Restriction digestion they belong to the same strain. Isolate 2 in the of the ITS region by AluI enzyme gave 2 DNA lane 11 which gave another banding pattern, bands around $400 \mathrm{bp}$ and $100 \mathrm{bp}$ sizes, except was also identified as $T$. viridae, confirming with isolate 9, suggesting that there is one AluI that there are three different $T$. viridae strains. site in the ITS region. According to the gel Among the rest of banding patterns that were picture, five different banding patterns of AluI given by AluI digestion, isolate 1 (lane 10) and digested DNA can be seen. There were similar isolate 3 (lane 12), which have been identified 
as T. harzianum gave two slightly different patterns. This confirms that these two were two T. harzianum strains and it was also confirmed by the presence (isolate 3 ) and absence (isolate 1) of pustules in the PDA plate.

\section{Biological Control Abilities of Trichoderma Species}

The growth of $C$. paradoxa is significantly reduced when both Trichoderma (BCA) ( $T$. viridae, T. harzianum, T. polysporum) and $C$. paradoxa (pathogen) are cultured in dual culture plates. The growth of $C$. paradoxa in the dual culture plate (Figure 02) is significantly lower than the growth in the single culture (Figure 03) which is incubated under similar conditions and same durations.

In almost all the dual culture plates, the contact zone appeared as a curve, with concavity oriented towards $C$. paradoxa (Figure 04). The radial growth of the colony of biocontrol agent and the colony of the pathogenic fungi in the same PDA plate depend on the growth rate of each colony. In this study, all Trichoderma isolates showed faster growth rate than C. paradoxa and it also serves as one of the characteristics of a good BCA.
The biological control potential of all Trichoderma isolates was determined through the average percentage inhibition of mycelial growth of pathogenic fungus: C. paradoxa. This approach is frequently used and shown to be a useful way in expressing the potential biological control ability of the biological control agent (Grondona et al., 1997).

Higher inhibition $(>40 \%)$ indicates that the particular Trichoderma isolate as a better biological control agent. According to the results obtained (Table 04) all Trichoderma isolates showed significantly higher percentage inhibitions which were increased with time. Among them, isolates 3, 6 and 10 (T. harzianum) initially exhibited the highest percentage inhibition while on the later days, they showed the lowest percentage inhibition, confirming that the isolates have low rate of inhibition of the pathogen (Figure 06). It suggests that these isolates are not very good BCA because after some time they reduce their biological control ability. However, those T. harzianum isolates exhibited inhibition to the mycelial growth of C. paradoxa prior to mycelial contact (Figure 05). This could be due to the production of diffusible antimicrobial compounds, such as lytic enzymes or water-soluble metabolites, by Trichoderma isolates (Grondona et al., 1997).

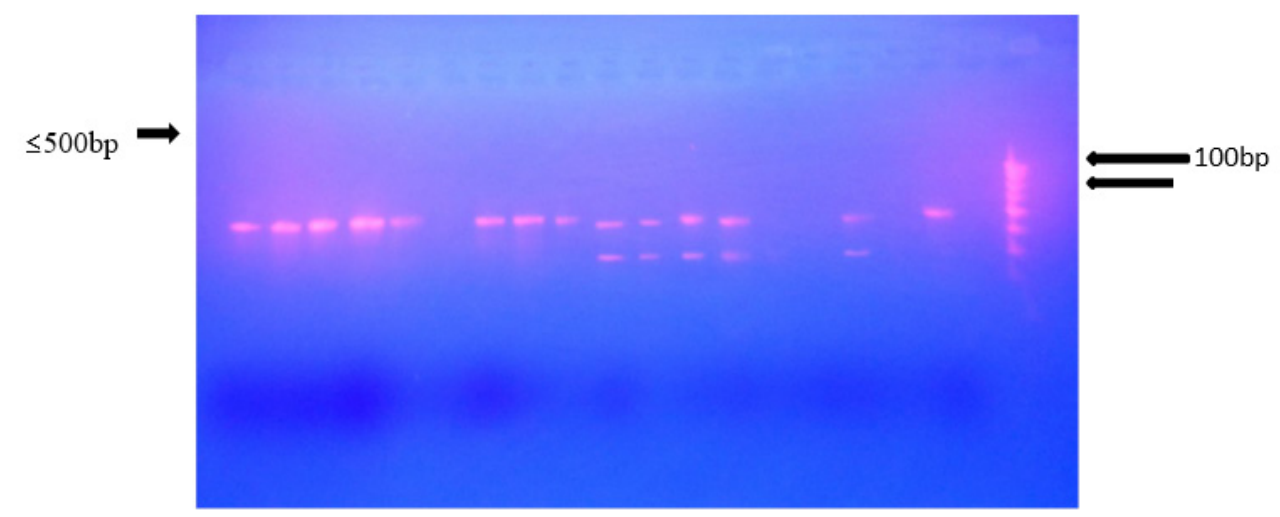

Figure 01: PCR amplified DNA of ITS regions and AluI digested DNA of ITS regions. Lane 1: undigested isolate 1; Lane 2: undigested isolate 2; Lane 3: undigested isolate 3; Lane 4: undigested isolate 4; Lane 5: undigested isolate 5; Lane 7: undigested isolate 7; Lane 8: undigested isolate 8; Lane 9: undigested isolate 9; Lane 10: AluI digested isolate 1; Lane 11: AluI digested isolate 2; Lane 12: AluI digested isolate 3; Lane 13: AluI digested isolate 4; Lane 16: AluI digested isolate 7; Lane 18: AluI undigested isolate 9; Lane 20: 100bp DNA ladder. 


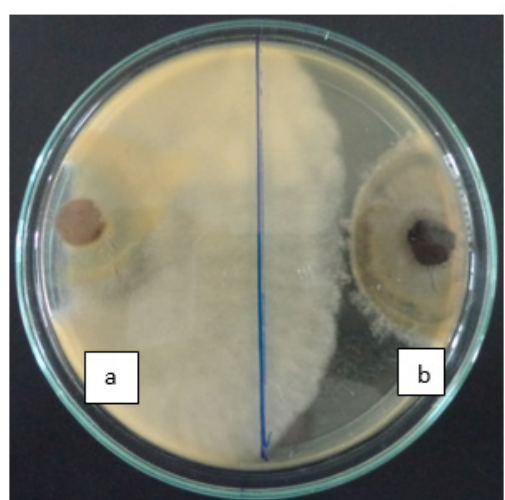

Figure 02: Four days old dual culture plate of T. viridae (a) and C. paradoxa (b) in PDA.

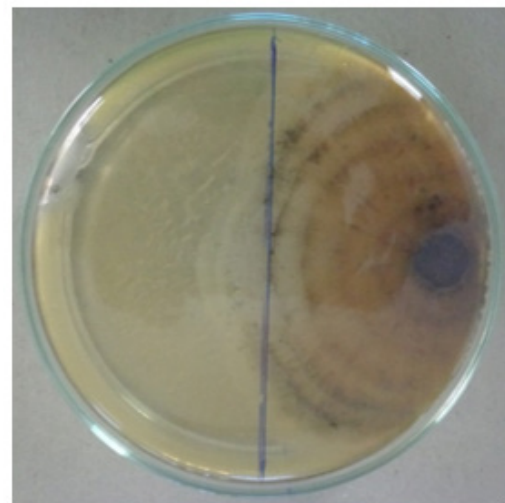

Figure 03: Four days old single culture plate of C. paradoxa in PDA

Table 04: Percentage inhibition of Ceratocystis paradoxa in the dual culture with Trichoderma

\begin{tabular}{lccccccc}
\hline \multirow{2}{*}{$\begin{array}{l}\text { Trichoderma isolate used } \\
\text { in the dual culture }\end{array}$} & \multicolumn{6}{c}{ Percentage inhibition of C. paradoxa in dual culture plate (\%) } \\
\cline { 2 - 8 } & Day 1 & Day 2 & Day 3 & Day 4 & Day 5 & Day 6 & Day 7 \\
\hline 1- T. harzianum & 7.41 & 17.5 & 25 & 46.84 & 55.79 & 61.82 & 69.12 \\
2- T. viridae & 3.70 & 15 & 23.21 & 39.24 & 47.37 & 52.73 & 61.76 \\
3- T. harzianum & 11.11 & 12.5 & 21.43 & 21.52 & 26.32 & 30 & 43.38 \\
4- T. viridae & 7.41 & 12.5 & 32.14 & 45.57 & 53.68 & 60 & 67.65 \\
5- T. polysporum & 11.11 & 15 & 23.21 & 37.97 & 47.37 & 52.73 & 61.76 \\
6- T. harzianum & 11.11 & 15 & 19.64 & 21.52 & 26.32 & 34.55 & 47.06 \\
7- T. viridae & 7.41 & 10 & 33.93 & 44.30 & 52.63 & 54.55 & 63.24 \\
8- T. harzianum & 7.41 & 20 & 25 & 45.57 & 54.74 & 60.91 & 68.38 \\
9- T. viridae & 3.70 & 12.5 & 25 & 39.24 & 47.37 & 52.73 & 61.76 \\
10- T. harzianum & 11.11 & 15 & 19.64 & 20.25 & 28.42 & 31.82 & 44.85 \\
\hline
\end{tabular}

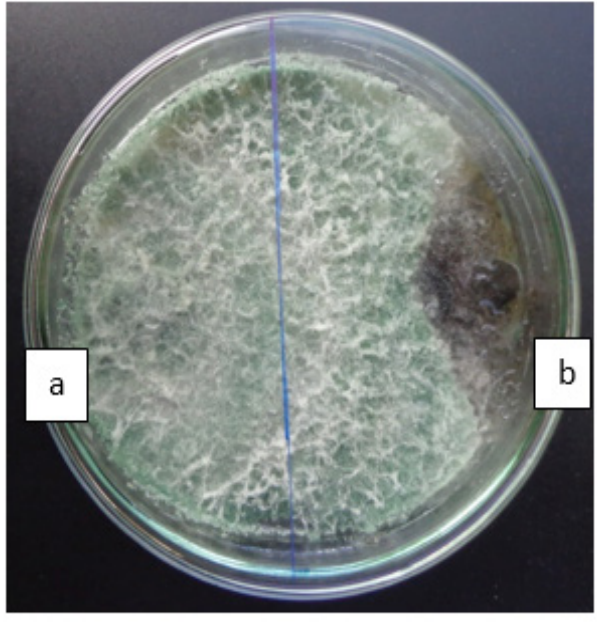

Figure 04: Six days old dual culture plate of T. viridae (a) and $C$. paradoxa (b) in PDA.

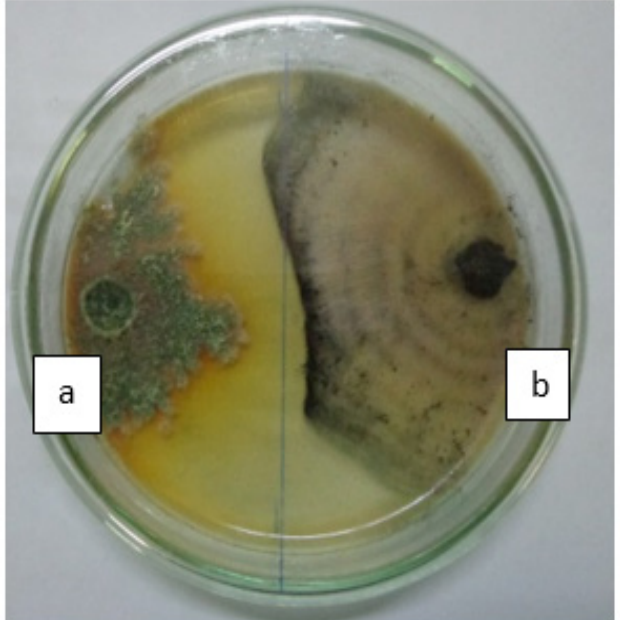

Figure 05: Four days old dual culture plate of $T$. harzianum (a) and C. paradoxa (b) in PDA. 


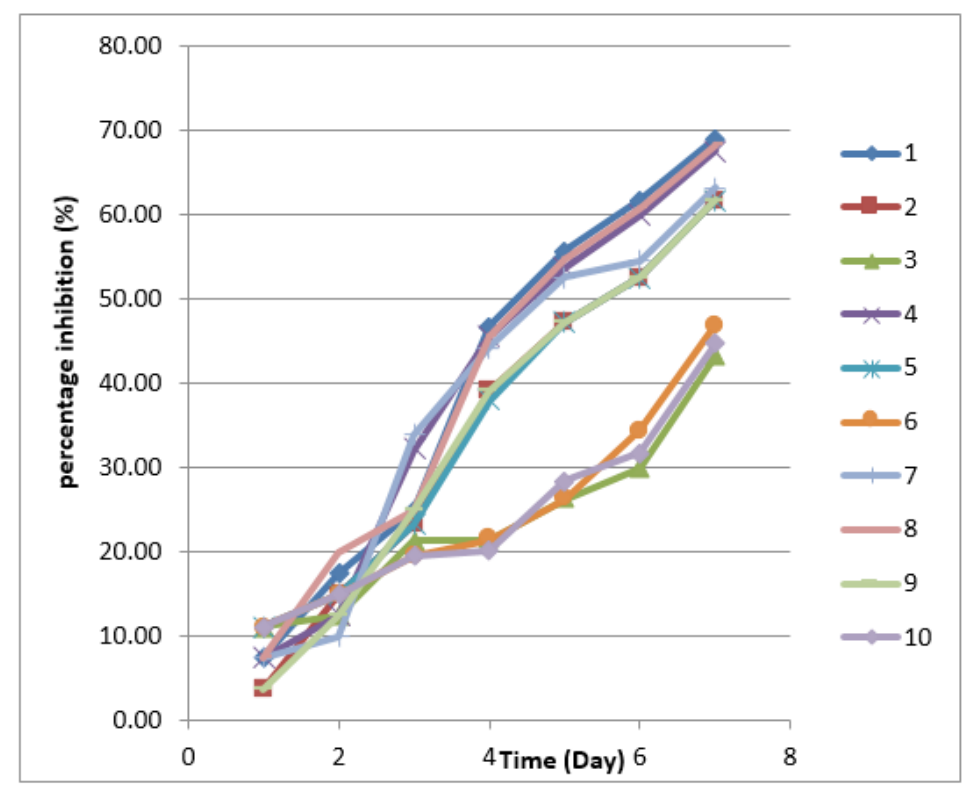

Figure 06: Percentage inhibition of $C$. paradoxa cultured with Trichoderma isolates in dual culture

T. harzianum in isolates 1 and 8 , and T. viridae in isolates 4 and 7 had relatively low percentage inhibition at the beginning while showing high percentage inhibitions later (Figure 05). Therefore, those isolates have the highest rate of inhibition of the pathogen. That makes them very effective BCAs because with time their biological control potentials increase. $T$. polysporum (isolate 5) and T. viridae isolates 2 and 9) have exhibited moderate rate of inhibition among the all isolates (Figure 06).

In this study, it was also found that the biological control abilities of different isolates that belong to the same assigned species vary. The previous studies have also reported that even the same Trichoderma species can exhibit different abilities to control the same pathogen in different occasions. In 1995 Jinantara have reported that $T$. harzianum possess different abilities to control Sclerotium rolfsii (Imtiaj and Lee, 2008).

The presence of different inhibition mechanisms in the same species at different situations has also been reported. This phenomenon could be due to the distinctive biological control mechanisms established by the isolates (Anees et al., 2010).
Another possible explanation for this situation is that the responsible gene expression efficiency of biological control abilities may be different in different isolates. The isolates that can express these genes more rapidly and efficiently are usually better biological control agents than the other isolates (Herman, 2006).

Although an attempt was made to observe hyphal interactions between the pathogen and the BCA in a dual culture by using slide culture method, it was unsuccessful because there were no significant hyphal interactions observed. But it has been reported that the mycelium intersections and the subsequent overlapping of hyphae of both BCA and the pathogen $C$. paradoxa began to form after 3 to 4 days and penetration in to the hyphae of pathogen began subsequently (Eziashi et al., 2007).

T. harzianum has been reported to have the ability to penetrate into the cell wall of resting spores and hyphae of other fungi which is attributed to the production of enzymes that catalyze the breakdown of chitin, a primary component of fungal cell walls of the pathogen (Brimner and Boland, 2003). 


\section{CONCLUSION}

This investigation sheds new light on the ways for the use of Trichoderma spp. in controlling the plant pathogen $C$. paradoxa which is one of the serious fungal pathogens which develops the stem bleeding in Cocos nusifera. The present results also reveal that the $T$. viridae, $T$. polysporum, and T. harzianum are capable of controlling the growth of $C$. paradoxa.

The precise benefits and consequences of the present findings open several avenues for future research in the field of biocontrol and biotechnology.

\section{ACKNOWLEDGEMENTS}

The authors wish to thank the staff of Coconut Research Institute at Lunuwila for providing guidance on collecting coir dust samples and providing related information. Our sincere gratitude is also conveyed to the Department of Microbiology and the Department of Botany of the University of Kelaniya, for the technical assistance provided throughout the research project and also to Miss Punnaja Ambadeniya for the help given in type setting.

\section{REFERENCES}

Anees, M., Tronsmo, A., Edel-Hermann, V., Hjeljord L, G., Heraud C. and Steinberg, C. (2010). Characterization of field isolates of Trichoderma antagonistic against Rhizoctonia solani, Fungal Biology. 114: 691-701.

Beckmann, J. S. and Soller, M. (1983). Restriction fragment length polymorphism in genetic improvement: methodologies, mapping and costs, Theoretical and Applied Genetics. 67: 3543.

Benítez, T., Rincon, A. M., Limon, M. C. and Antonio, C. C. (2004). Biocontrol mechanisms of Trichoderma strains, International Microbiology. 7: 249-260.

Brimner, T. A. and Greg, J. Boland. (2003). A review of the non-target effects of fungi used to biologically control plant diseases, Agriculture, Ecosystems and Environment. 100: 3-16.

Chakraborty, B. N., Chakraborty, U., Saha, A., Dey, P. L. and Sunar, K. (2010). Molecular Characterization of Trichoderma viride and Trichoderma harzianum Isolated from Soils of North Bengal Based on rDNA Markers and Analysis of Their PCR-RAPD Profiles, Global Journal of Biotechnology \& Biochemistry 5: 55-61.

Domsch, K. H., Gams, W., and Anderson, T. H. (1980). Compendium of soil fungi. Volume 1, (Ed. I. H. W.Verlag), Eching, Germany.

Eziashi, E. I., Omamor, I. B. and Odigie, E. E. (2007). Antagonism of Trichoderma viride and effects of extracted water soluble compounds from Trichoderma species and benlate solution on Ceratocystis paradoxa, African Journal of Biotechnology. 6: 388-392.

Eziashi, E.I., Uma, N.U., Adekunle, A.A. and Airede, C.E. (2006). Effect of metabolites produced by Trichoderma species against Ceratocystis paradoxa in culture medium, African Journal of Biotechnology. 5: 703-706. 
Eziashi, E. I., Uma, N. U., Adekunle, A. A., Airede1, C. E. and Odigie, E. E. (2010). Evaluation of lyophilized and non-lyophilized toxins from Trichoderma species for the control of Ceratocystis paradoxa, African Journal of Agricultural Research. 5: 1733-1738.

Flegel, T. W. (1980). Semipermanent microscope slides of microfungi using sticky tape technique, Canadian Journal of Microbiology. 26: 551-553.

Grondona, I., Hermosa, R., Tejada, M., Gomis, M. D., Mateos, P. F., Bridge, P. D., Monte, E. and Garcia-Acha, I. (1997). Physiological and biochemical characterization of Trichoderma harzianum, a biological control agent against soilborne fungal plant pathogens, Applied Environmental Microbiology. 63(8): 3189.

Herman, G. E. (2006). Overview of mechanisms and uses of Trichoderma species, Phytopathology. 96: 190-194.

Imtiaj, A. and Lee, T. S. (2008). Antagonistic effect of three Trichoderma species on the Alternaria porri pathogen of onion blotch, World Journal of Agricultural sciences. 4: 13-17.

Mbwana, J., Bölin, I., Lyamuya, E., MhAlu, F. and Legergard, T. (2006). Molecular characterization of Haemophilus ducreyi isolates from different geographical locations, Journal of Clinical Microbiology. 44(1): 132-137.

Paulin-Mahady, A.E., Harrington, T.C. and McNew, D.L. (2002). Phylogenetic and taxonomic evaluation of Chalara, Chalaropsis, and Thielaviopsis anamorphs associated with Ceratocystis, Mycologia. 94: 62- 72.

Samuels, G. J., Chaverri P., Farr, D. F. and Mccray, E.B. (2002). Trichoderma species associated with the green mold epidemic of commercially grown Agaricus bisporus, Mycologia. 94: 146-170.

Sanchez, V., Rebolledo, O., Picaso, R. M., Cardenas, E., Cordova, J. and Samuels, G. J. (2006). In vitro antagonism of Theieloviopsis paradoxa by Trichoderma longibrachiatum, Mycopathologia. 163: 49-58.

Schoh, C. L., Seifert K. A., Huhndorf S., Robert, V., Spouge, J. L., Levesque, C. A. and Chen, W. (2012). Nuclear ribosomal internal transcribed spacer (ITS) region as a universal DNA barcode marker for Fungi, Proceedings of the National Academy of Sciences of the United State of America. 109 (16): 6241-6246.

Shahid, M., Anuradha Singh, Mukesh Srivastava, Smita Rastogi and Neelam Pathak. (2013). Sequencing of 28S rRNA gene for identification of Trichoderma longibrachiatum 28CP/7444 species in soil sample, International Journal of Biotechnology for Wellness Industries. 2: 8490 .

Talukder, M. I., Begum, F. and Azad, M. M. K. (2007). Management of pineapple disease of sugarcane through biological means, Journal of Agriculture \& Rural Development. 5: 79-83.

Warwick, D. R. N., and Passos, E. E. M. (2009). Outbreak of stem bleeding in coconuts caused by Thielaviopsis paradoxa in Sergipe, Brazil, Tropical Plant Pathology. 34: 175-177. 
White, T. J., Bruns, T., Lee, S. and Taylor, J. (1990). Amplification and direct sequencing of fungal ribosomal RNA genes for phylogenetics. In: PCR Protocoles: A Guide to Methods and Applications. (Innis, M. A., Gelfand, D. H., Sninsky, J. J., White, T. J. Eds.). Academic Press, Inc, California. 315-322.

Wijesekara, H. T. R., Rajapakse, C. N. K., Fernando, L. C. P., Jayasinghe, C. K., Manoher, S. P. and Perera, K. F. G. (1998). Stem bleeding incidence of coconut in Hambantota district, Cocos. 13: 21-29. 